\title{
Effects of artificial diets on growth and mortality of Rainbow Trout (Oncorhynchus mykiss) larvae
}

\author{
Suren Subba ${ }^{1}$ and Surya Ratna Gubhaju ${ }^{2}$ \\ ${ }^{1}$ Institute of Science and Technology, Dhankuta Multiple Campus, Dhankuta \\ ${ }^{2}$ Central Department of Zoology, Tribhuvan University, Kirtipur, Kathmandu, Nepal
}

\begin{abstract}
Trout larvae of average weight of 0.08391 to 0.08907 gm were nursed in 12 floating net cages set in a circular tank. The larvae were fed with 4 different diets- Diet 1 (normal diet), Diet 2 (normal diet with buff liver), Diet 3 (normal diet with chicken liver) and Diet 4 (normal diet with mutton liver). The experiment was conducted at completely randomized design (CRD) with three replications for each diet. Body weight, total length and condition factor of larvae did not show significantly variation at different test diets. The specific growth rate was recorded $3.043 \%$ per day which was highest in test diet 3. The highest Food Conversion Ratio (FCR) i.e., 2.8768 was recorded in diet 4. Physico-chemical parameters and the survival rate were also recorded. The correlation coefficient of length and weight relationship was highest (0.972) in diet 3.
\end{abstract}

Key words: Raibow trout, larvae, artificial diets, growth and mortality.

\section{Introduction}

Fish farming is established as a promising industry in Nepal. About 366000-439000 people or around $2 \%$ of the total population are benefited directly from aquaculture and fisheries (Thapa \& Pradhan, 1999). Fish farm production, especially the carp production has been practiced widely with substantial increment in Terai regions. However, commercial farming of cold water fishes is comparatively less developed but has gained more attention in recent days. A large number of fish species are found in Nepal and offer an opportunity for developing of inland fisheries in the country. Several exotic fishes of commercial value have been imported in Nepal.

Rainbow trout (Oncorhynchus mykiss) is a cold water fish which has been introduced in Nepal to promote cold water fisheries. It is high oxygen demanding carnivorous fish, contains high protein (40-50\%). Rainbow trout was bred for the first time in 1990, culture experiments were initiated in 1993 and production was started from 1995 and 1998 by the Government and private farms respectively in Nepal (Aryal et al., 2008; Rai et al., 2008). Hence trout farming in Nepal has a fairly short history. The research works carried out by NARC during past 10 years have demonstrated appreciable achievements in trout farming practices by developing suitable trout farming system in the country. It is a suitable fish for intensive aquaculture, sport fishery (Rai, 2005) and possess high economic prospect providing ample of opportunities for commercial production in mid and high hill area (Singh, 2008). Basnet et al. (2008) had described that supplement feed took about 70\% weightage of cost for trout fish farming. 
Trout including catfishes required a non-specific nitrogen sources and indispensable amino acids (Robinson \& Li, 1996). Despite of low protein content, moist or dry buff liver has proved to be a good source of digestible protein for early stage of trout grows out (Pradhan, 1999). Blood meal, prepared by heating and grinding of clotted animal blood (buffalo, or goat) contains 80 to $86 \%$ crude protein and is an excellent source of lysine (Robinson \& Li, 1996).Trout larvae, fed upon fresh buff liver and egg custard, grow steadily at specific growth rate SGR of $4.2 \%$ with survivability over $99 \%$ (Pradhan, 1999). However, there are limited reports pertaining to the response of trout larvae towards mutton, buff and chicken liver. The present attempt was the introduction of these three in the starter feed to meet the nutritional requirement of young trout.

\section{Material and Methods}

The present work was done in Fisheries research Division (FRD), Godawari. For the study, trout larvae produced in Godawari, FRD were used for experimental purposes. The average initial weight and the length of the larvae varied from $0.08274 \mathrm{gm}$ to $0.08706 \mathrm{gm}$ and 1.58 to $2.13 \mathrm{~cm}$ respectively. Trout larvae were fed with 4 types of feed which were as follows:

1. Diet 1: Normal feed was mad up of shrimp, soybean, wheat flour, powder milk, egg, bread yeast, vitamin $\mathrm{C}$ and minerals.

2. Diet 2: Normal feed plus buff liver cakes.

3. Diet 3: Normal diet plus chicken liver cakes.

4. Diet 4: Normal diet plus mutton liver cakes.

The experiment was conducted on 12 floating net cages with three replications for each feed. Each cage was of size $34 \times 34 \times 36 \mathrm{~cm}^{3}$. Hundred and fifty trout larvae were stocked in each experimental cage. The flow of clean freshwater was maintained in the tank and the cages were cleaned manually by brushing and washing everyday. Dead larvae were counted and removed by siphoning daily.

Physico-chemical parameters were recorded twice a day at 9.00 am and 4.00 pm every day. Temperature and $\mathrm{pH}$ were recorded by simple Celsius thermometer and $\mathrm{pH}$ meter respectively. Dissolved Oxygen was estimated by DO meter and by titration method following Winkler's Iodometric method.

The growth rate was checked up regularly every fortnight. For the study of growth rate, 10 larvae were taken out from each cage with the help of a simple scoop net and length measured. The weight of the fish was recorded using digital balance and length was measured by using a Vernier's Calipers.

The growth of the larvae was calculated by using the Fulton's formula of condition factor. Relationship between weight and length of trout was calculated by using coefficient of correlation following Karl Pearson (Gupta, 1988). Fish survival rate (S) was calculated as the number of fish harvested $(\mathrm{Nf})$ as percentage of the number of fish stocked $(\mathrm{Ni}): \mathrm{S}(\%)=(\mathrm{Nf} / \mathrm{Ni}) * 100$

Data and statistical analyses were performed using Microsoft ${ }^{\circledR}$ Excel-add-in-DDXL, and Graph Pad Prism 5 softwares. All data were checked for homogeneity of variance. 


\section{Results and Discussion}

The productivity of fish is directly or indirectly affected by physicochemical parameters. Weekly mean readings of temperature, $\mathrm{pH}$ and DO (Table 1)

Table 1. Physicochemical parameters

\begin{tabular}{llllllllll}
\hline Parameters & $\begin{array}{c}\mathbf{1}^{\text {st }} \\
\text { week }\end{array}$ & $\begin{array}{c}\text { 2nd } \\
\text { week }\end{array}$ & $\begin{array}{c}\text { 3rd } \\
\text { week }\end{array}$ & $\begin{array}{c}\text { 4th } \\
\text { week }\end{array}$ & $\begin{array}{c}\text { 5th } \\
\text { week }\end{array}$ & $\begin{array}{c}\text { 6th } \\
\text { week }\end{array}$ & $\begin{array}{c}\text { 7th } \\
\text { week }\end{array}$ & $\begin{array}{c}\text { 8th } \\
\text { week }\end{array}$ & $\begin{array}{c}\text { 9th } \\
\text { week }\end{array}$ \\
\hline Temperature & 10.71 & 10.07 & 9.78 & 10.82 & 11.96 & 11.75 & 12.14 & 12.46 & 12.5 \\
\hline pH & 8.5 & 7.96 & 7.4 & 7.15 & 7.17 & 7.17 & 7.83 & 7.56 & 7.0 \\
\hline DO & 8.27 & 8.80 & 9 & 8.54 & 8.5 & 7.5 & 6.5 & 8.0 & 8.0 \\
\hline
\end{tabular}

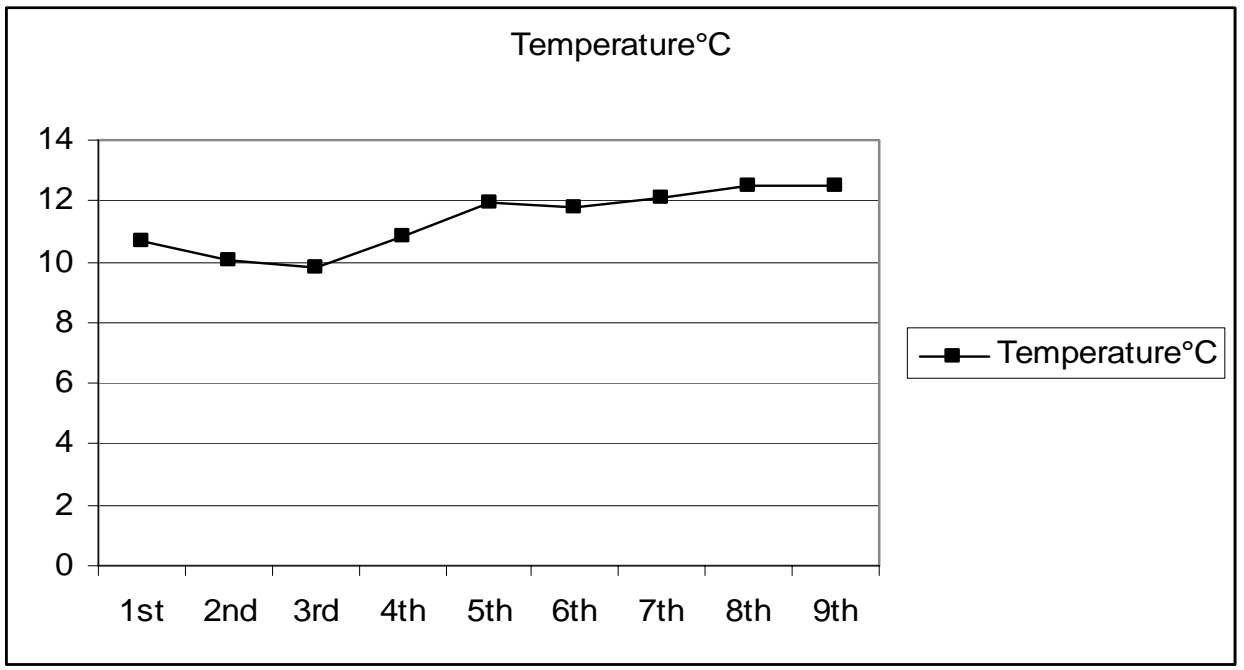

Figure 1. Variation of temperature.

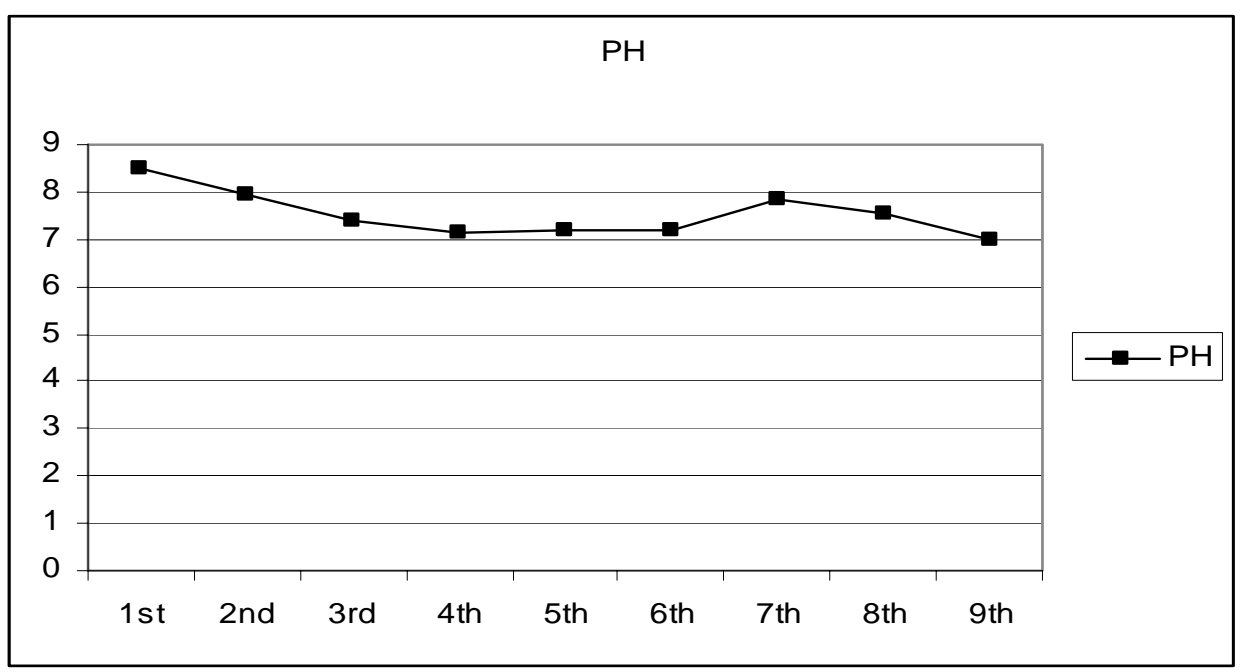

Figure 2. Variation of $\mathrm{pH}$. 


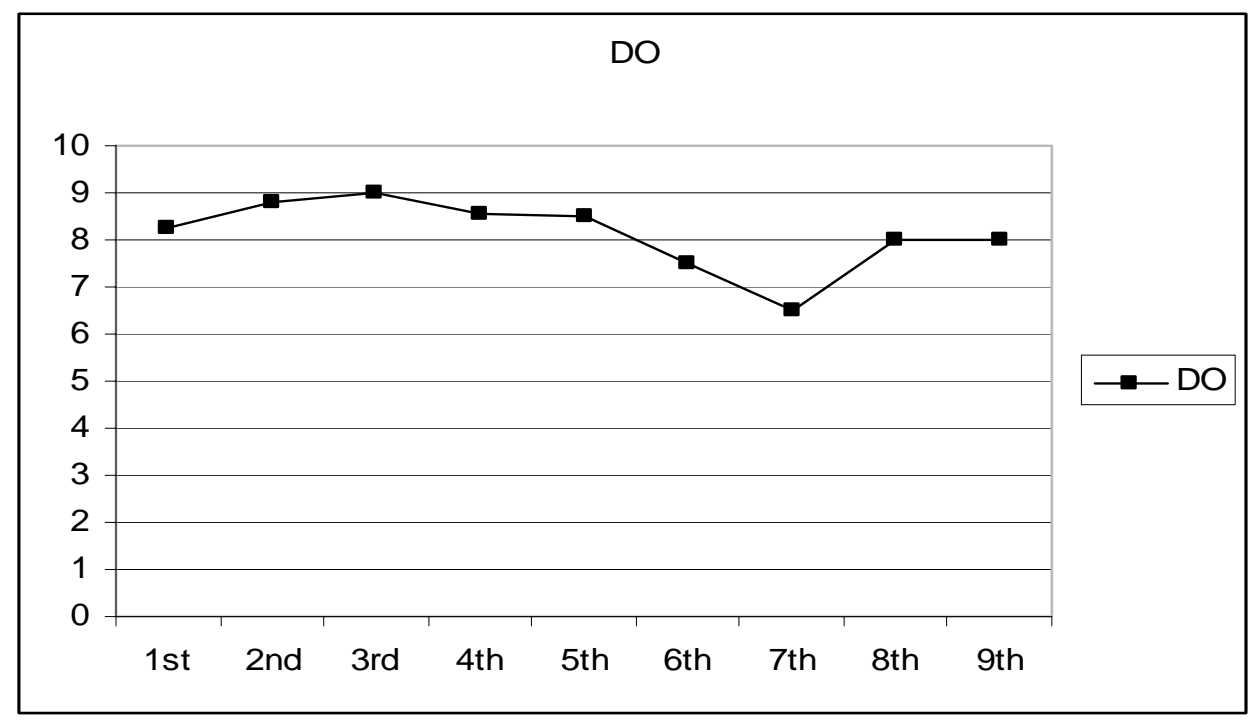

Figure 3. Variation of DO

The highest growth was observed in larvae fed with normal diet plus chicken liver while the lowest growth was observed in the larvae fed with normal diet with no liver supplement (Table 2).

Table 2. Comparative growth increases in different diets.

\begin{tabular}{|c|c|c|c|c|c|c|}
\hline$\frac{\text { Duration }}{\text { Diets }}$ & Replicate & $\begin{array}{c}\text { Initial } \\
\text { Wt. (gm) }\end{array}$ & 15 days & 30 days & 45 days & 60 days \\
\hline \multirow{4}{*}{ Diet- 1} & $\overline{\mathrm{R} 1}$ & 0.08602 & 0.11276 & 0.12336 & 0.1549 & 0.14098 \\
\hline & R2 & 0.08907 & 0.13085 & 0.12105 & 0.14255 & 0.17055 \\
\hline & R3 & 0.07312 & 0.113 & 0.11495 & 0.17097 & 0.13596 \\
\hline & Mean & 0.08274 & 0.11887 & 0.11979 & 0.15614 & 0.14917 \\
\hline \multirow{4}{*}{ Diet- 2} & R1 & 0.08791 & 0.14215 & 0.25192 & 0.21608 & 0.49579 \\
\hline & $\mathrm{R} 2$ & 0.07705 & 0.14544 & 0.25083 & 0.23237 & 0.52476 \\
\hline & R3 & 0.08391 & 0.14833 & 0.2735 & 0.22475 & 0.50268 \\
\hline & Mean & 0.08296 & 0.14530 & 0.25875 & 0.2244 & 0.50775 \\
\hline \multirow{4}{*}{ Diet- 3} & R1 & 0.08566 & 0.1973 & 0.27499 & 0.27385 & 0.52183 \\
\hline & $\mathrm{R} 2$ & 0.08732 & 0.20117 & 0.3089 & 0.27673 & 0.55333 \\
\hline & R3 & 0.08569 & 0.19559 & 0.31173 & 0.27117 & 0.53024 \\
\hline & Mean & 0.08622 & 0.19802 & 0.29854 & 0.27392 & 0.53514 \\
\hline \multirow{4}{*}{ Diet- 4} & R1 & 0.08753 & 0.15878 & 0.23756 & 0.24532 & 0.44001 \\
\hline & $\mathrm{R} 2$ & 0.08603 & 0.15384 & 0.2256 & 0.22989 & 0.43225 \\
\hline & R3 & 0.08762 & 0.15906 & 0.23453 & 0.23587 & 0.42727 \\
\hline & Mean & 0.08706 & 0.15723 & 0.23257 & 0.23703 & 0.43318 \\
\hline
\end{tabular}


Table 3. Comparative length increases in different diets.

\begin{tabular}{|c|c|c|c|c|c|c|}
\hline $\begin{array}{c}\text { Duration } \\
\text { Diets } \\
\end{array}$ & Replicates & $\begin{array}{c}\text { Initial } \\
\text { Length }(\mathbf{c m}) \\
\end{array}$ & 15 days & 30 days & 45 days & 60 days \\
\hline \multirow{4}{*}{ Diet-1 } & $\mathrm{R} 1$ & 1.92 & 2.41 & 2.16 & 2.63 & 2.65 \\
\hline & $\mathrm{R} 2$ & 2 & 2.43 & 2.18 & 2.35 & 2.76 \\
\hline & R3 & 1.88 & 2.46 & 2.38 & 2.58 & 2.56 \\
\hline & Mean & 1.94 & 2.44 & 2.24 & 2.52 & 2.66 \\
\hline \multirow{4}{*}{ Diet- 2} & R1 & 1.68 & 2.49 & 2.48 & 2.53 & 3.69 \\
\hline & $\mathrm{R} 2$ & 1.58 & 2.53 & 2.67 & 2.81 & 3.72 \\
\hline & R3 & 1.93 & 2.48 & 2.53 & 2.96 & 3.85 \\
\hline & Mean & 1.73 & 2.5 & 2.56 & 2.77 & 3.76 \\
\hline \multirow{4}{*}{ Diet- 3} & R1 & 1.92 & 2.67 & 2.76 & 3.16 & 3.95 \\
\hline & R2 & 1.99 & 2.88 & 2.74 & 2.94 & 4.01 \\
\hline & R3 & 1.72 & 2.6 & 2.8 & 3.26 & 4.11 \\
\hline & Mean & 1.88 & 2.72 & 2.77 & 3.12 & 4.02 \\
\hline \multirow{4}{*}{ Diet- 4} & $\mathrm{R} 1$ & 2.13 & 2.45 & 2.5 & 2.81 & 3.8 \\
\hline & $\mathrm{R} 2$ & 1.98 & 2.47 & 2.52 & 2.53 & 4.11 \\
\hline & R3 & 1.7 & 2.53 & 2.64 & 2.75 & 3.86 \\
\hline & Mean & 1.94 & 2.48 & 2.55 & 2.70 & 3.92 \\
\hline
\end{tabular}

Feed conversion ratio was determined at the end of the research period. Resulted weight gain with feed supply was calculated in total yield of individual i.e., 150 larvae. By the end of the study, total feed consumed in each replicate was $14.01 \mathrm{gm}$ of diet-1, 149.36 gm of diet- 2, 149.36 gm of diet-3 and 149.36 gm of diet- 4 (Table 4).

Table 4. Feed conversion ratio in trout larvae in different diets.

\begin{tabular}{cccc}
\hline Diets & Feed consumed (gm) & Total Wt. gain & FCR \\
\hline Diet- 1 & 14.01 & 9.9645 & 1.4059 \\
Diet- 2 & 149.36 & 63.7185 & 2.3441 \\
Diet- 3 & 149.36 & 67.338 & 2.2181 \\
Diet- 4 & 149.36 & 51.918 & 2.8768 \\
\hline
\end{tabular}

Lowest mortality was recorded in diet 3 followed by diet 2, diet 4 and highest mortality was observed for diet 1 .

Table 5. Survivability rate of the trout larvae.

\begin{tabular}{lccccccc}
\hline Diets & Replicate & $\begin{array}{c}\text { No. of fish } \\
\text { stocked }\end{array}$ & $\begin{array}{c}\text { No. of fish } \\
\text { harvested }\end{array}$ & $\begin{array}{c}\text { Survival } \\
\text { Rate (\%) }\end{array}$ & $\begin{array}{c}\text { Mean } \\
\text { (Survival) }\end{array}$ & $\begin{array}{c}\text { Mortality } \\
\text { rate }\end{array}$ & $\begin{array}{c}\text { Mean } \\
\text { (Mortality) }\end{array}$ \\
\hline \multirow{2}{*}{ Diet 1 } & R1 & 150 & 90 & 60 & & 40 & \\
& R2 & 150 & 85 & 56.67 & 55.11 & 43.33 & 44.89 \\
& R3 & 150 & 73 & 48.67 & & 51.33 & \\
\hline \multirow{2}{*}{ Diet 2 } & R1 & 150 & 97 & 64.67 & & 35.33 & \\
& R2 & 150 & 124 & 82.67 & 77.34 & 17.33 & 22.66 \\
& R3 & 150 & 127 & 84.67 & & 15.33 & \\
\hline \multirow{3}{*}{ Diet 3 } & R1 & 150 & 114 & 76.0 & & 24.0 & \\
& R2 & 150 & 109 & 72.67 & 76.22 & 27.33 & 23.78 \\
& R3 & 150 & 120 & 80.0 & & 20.0 & \\
\hline \multirow{3}{*}{ Diet 4 } & R1 & 150 & 101 & 67.33 & & 32.67 & \\
& R2 & 150 & 117 & 78.0 & 76 & 22.0 & 24 \\
\hline & R3 & 150 & 124 & 82.67 & & 17.33 & \\
\hline
\end{tabular}




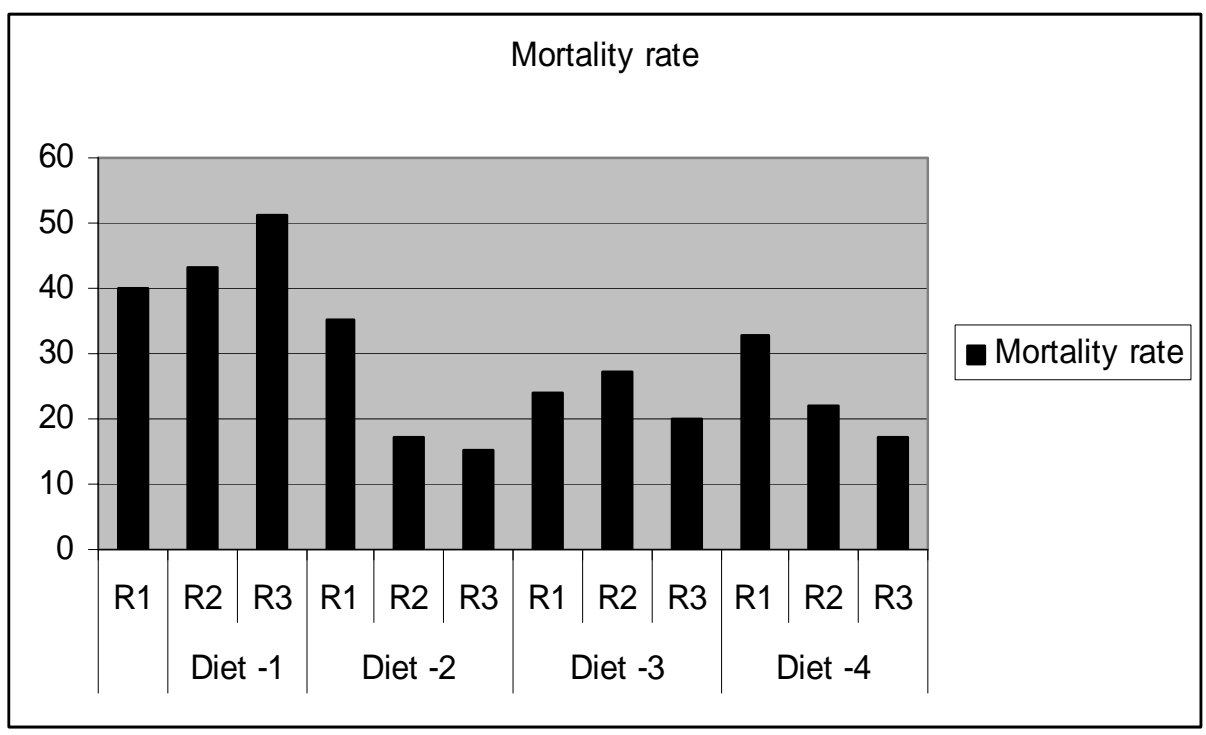

Figure 4. Mortality rate

Specific Growth Rate (SGR) was found highest in diet 3 i.e., 3.043. The value was found slightly higher than in diet 2 i.e. 3.0175.SGR in diet 4 and in diet 1 were 2.6745 and 0.9823 respectively.

Quality feed supply is one of the major constraints after seed supply to expand trout farming in Nepal. Therefore, most of the studies have been focused on finding alternate source of protein supplement in trout feed which are locally available at relatively cheaper cost without affecting the growth, production and quality of trout. The availability of nutrient diet, palatability or acceptability, processing and storage methods is important aspects of trout culture. Besides it, attention should be in economically sound feed formulation for the success of trout industry. Buff liver constituted one of the major components in formulated diet for larval rearing of trout. The present investigation was done to develop possible alternatives for the buff liver portion in the starter feed for trout larvae.

\section{Water quality}

Water quality refers the extent to which water is biologically, chemically and physically suitable to specific purpose; such as fishery, aquaculture, irrigation, water recreation and water sports (Boyd et al., 1979). To great extent water quality determines the success or failure of an aquaculture operation.

The temperature, DO and $\mathrm{pH}$ did not fluctuate beyond the limit during the study period. Temperature ranged from 8 to $13^{\circ} \mathrm{C}$ during the study period and this range proved to suitable for the growth of larvae as reported by Yamazaki (1991) water temperature in between from 10 to $18^{\circ} \mathrm{C}$ suitable for trout suitable farming. DO range from 6.5 to $9 \mathrm{mg} / \mathrm{l}$ and $\mathrm{pH}$ from 7.0 to 8.5 and suitable for the growth of the trout larvae. The $\mathrm{pH}$ value of 6.5 to 8.5 and DO above $8 \mathrm{mg} / \mathrm{L}$ are reported suitable for trout culture (Huet, 1975).

\section{Growth measurement}

Fish continue to grow practically throughout life; however in extreme old age growth is extremely slow. The growth rate is influenced by many physical factors, population 
density and feed supply throughout the life. In present study, trout larvae showed satisfactory growth with all types of liver supplement. The highest growth rate $(0.0075$ $\mathrm{gm}$ /day) was recorded for the larvae fed with diet with chicken liver supplement and was lowest $(0.001108 \mathrm{gm} /$ day $)$ in diet without liver. Mean individual body weight at the end of the study period was highest for the fishes fed with chicken liver. However, condition factor value was highest for fishes fed with diet with mutton liver.

Average initial weights of larvae were $0.0827 \mathrm{gm}, 0.0829 \mathrm{gm}, 0.0863 \mathrm{gm}$ and 0.0871 gm in diet-1, diet-2, diet-3 and diet-4, respectively. At the end of the study the larvae grew up to $0.1492 \mathrm{gm}$ and $2.66 \mathrm{~cm}$ in diet-1, $0.5078 \mathrm{gm}$ and $3.74 \mathrm{~cm}$ in diet-2, 0.5352 gm and $4.03 \mathrm{~cm}$ in diet-3 and $0.4332 \mathrm{gm}$ and $3.93 \mathrm{~cm}$ in diet-4. In the similar study, trout larvae fed upon buff liver and egg custard grew steadily at specific growth rate (SGR) of 4.2\% (Pradhan, 1999)

Buff liver has proved to be a good source of digestible protein for the early stage of trout. However, experiment with chicken liver and mutton liver have not yet been conducted in the country although these liver contain less fat and are more digestible. This is not practiced in fish farming in Nepal. The underlying reason may be due to relative high price and limited availability.

Feed conversion ratios were significant in all the types of feed. Most significant was found for diet-1 (1.4059) followed by diet-3 (2.2181), diet-2 (2.344) and diet-4 (2.8768). Feed efficiency (FE) was significantly different in normal diet and highest i.e., 71.12. Whereas feed efficiency of other feeds were low i.e., 45.08 in normal diet with chicken liver, 42.66 in diet with buff liver and 34.76 in diet with mutton liver. SGR was maximum in diet-3 (3.043) followed by diet-2 (3.0175), diet-4 (2.6745) and then diet-1 (0.9823). During the study period, SGR was lowest when the growth was slowest (Table 4). It may be due to less feed and the amount of feed intake was increased after $2^{\text {nd }}$ followed by high SGR.

Survival rate was found to be satisfactory. Diet with buff liver showed least mortality (22.66\%), followed by diet with chicken liver (23.78\%) and diet with mutton liver (24\%); but, and mortality was found highest in diet-1 (44.89\%) (Table 5). In the study conducted at FRC, Trishuli (2002) with different types of feed with different levels of crude protein (CP), survivability ranged from 36 to $79 \%$. High survival occurred during study period may be attributed to careful handling, without any disease out breaking out and lack of avian predation.

\section{Acknowledgements}

My heartfelt thanks and gratitude are due first of all to my respected teacher, Prof. Dr. S.R. Gubhaju, for providing me with continuous guidance, valuable suggestions, insightful comments, constant encouragement and meticulous supervision in accomplishing this report. I am also equally grateful to honorable Prof. Dr. J. Shrestha, Prof. Dr. T.K. Shrestha, Prof. Dr. V.K. Thapa, Prof. Dr. A.S. Tamrakar, Dr. A. Prasad and all my teachers for enlightening me in various subjects in fish and fisheries and stimulating me with diverse assistance. My sincere thanks go to all the faculties and staff of central department of zoology. I would also like to express my thanks to respected Director of NARC (Fish \& Livestocks), Dr. T.B. Gurung, Chief FRD, Godawari, Mr. S.K. Wagle, Senior Scientist, Mrs N. Pradhan, Mrs. A. Rayamajhi, Mr. R.M. Mulmi, Mr. N.K. Roy, Mr. M. K.C. and other scientists at FRD, for their kind cooperation and help. I am keen indebted to all the technicians and staffs at FRD, 
Godawari, who unselfishly and untiringly helped me a lot by answering my tedious questions in collecting data for the study, despite their own busy works.

\section{References}

Aryal, S.P. \& M.N. Paudel. 2008. GIS based potentiality of Rainbow trout (Oncorhynchus mykiss) farming in northern high hills, Rasuwa, Nepal. In: Proceedings of the workshop on "Rainbow trout farming scaling-up strategies in Nepal" (Ed. T.B. Gurung). pp. 109-114.

Basnet, S.R., G.P. Lamsal, R.M. Mulmi \& T.B. Gurung. 2008. Breeding performance of Rainbow trout (Oncorhynchus mykiss) in northeastern hills, Nepal. In: Proceedings of the workshop on "Rainbow trout farming scaling-up strategies in Nepal" (Ed. T.B. Gurung). pp. 32-36.

Boyd, C.E., R.P. Romaire \& E. Johnston. 1979. Water quality in channel catfish production ponds. Journal of Environmental Quality 8: 423-442.

Huet, M. 1975. Textbook of fish culture, breeding and cultivation of fish. Fishing News (Books) Ltd., 23 Rosemount Avenue, West Byfleet, Surrey, England.

Pradhan, N. 1998. Development of starter feed for trout larvae under local management. In: Present status of fisheries, research, development and education in Nepal (Eds. B.R. Pradhan, S.R. Wagle, Y. Osamu \& T. Masakazu). NARC \& JICA. 170 p.

Pradhan, N., A. Rayamajhi \& S.K. Shrestha. 2008. Rainbow trout (Oncorhynchus mykiss) larval rearing methodologies in Nepal. In: Proceedings of the workshop on "Rainbow trout farming scaling-up strategies in Nepal" (Ed. T.B. Gurung). pp. 3741.

Rai, A.K., R.C. Bhujel, S.R. Basnet \& G.P. Lamsal. 2005. Rainbow trout (Oncorhynchus mykiss) culture in the Himalayan Kingdom of Nepal- A success story. Asia-Pacific Association of Agricultural Research Institutions (APAARI), FAO, Regional Office for Asia and the Pacific Bangkok, Thailand. 33 p.

Rai, A.K., T.B. Gurung, S.R. Basnet \& R.M. Mulmi. 2008. Present status and prospect of Rainbow trout (Oncorhynchus mykiss) farming in Nepal. In: Proceedings of the workshop on "Rainbow trout farming scaling-up strategies in Nepal" (Ed. T.B. Gurung). pp. 25-30.

Robinson, E.H. \& M.H. Li. 1996. A practical guide to nutrition, feeds and feeding of Catfish. MSU Cares, Mississipi Agricultural and Forestry Experiment Station, Bulletin, 1041.

Singh, D.M., S.P. Dahal, B.C. Shrestha \& R.M. Mishra. 2008. Extension strategies for Rainbow trout (Oncorhynchus mykiss) aquaculture development in Nepal. In: Proceedings of the workshop on "Rainbow trout farming scaling-up strategies in Nepal" (Ed. T.B. Gurung). pp. 136-139.

Thapa, T.B. \& G.B.N. Pradhan. 1999. Status of aquaculture and its potential for expansion under long-term perspective plan in Nepal. In: Proceedings of the National Workshop on the prospect of Fisheries Development under the Agriculture Perspective Plan (Eds. D.B. Swar, G.B.N. Pradhan \& J. Bisgaard). Kathmandu, Inland Aquaculture and Fisheries Section, FDO, DOA, MOA, HMG Nepal.

Yamazaki, T. 1991. Culture of foreign origin fishes. Farming Japan 25(1): 41-46. 